\title{
Introduction
}

\section{Ways of Seeing, Strategies of Writing}

\author{
Rila MUKHERJEE*
}

This special issue of $A R W H$ interrogates some of the themes, topics and tropes current in world history and engages with the diverse ways these can be written into world history. Containing select papers from the conference Writing World History, organised by the Institut de Chandernagor, India and sponsored by the Indian Council of Historical Research, New Delhi, and the Department of Higher Education, Govt. of West Bengal in November 2013, the collection asks: Can cross/trans-border histories be called world history? Are the resulting new regional histories world histories? Are all cross-cultural/trans-regional /trans-national currents necessarily global? Is maritime/oceanic history part of world history? And finally, can one write a global history taking the sea as category?

The essays by Chakravarti and Polonia underline the various possibilities revealed by a novel construction of a region across and without borders and which promise to be truly transnational and trans-historical. Such possibilities may fully blossom in the writing of a world history in the future, but for now a problem remains; Pearson's essay sounding a skeptical note, namely that there are too many locales and regions on our globe for a valid overarching analysis to be possible. 
Seas and oceans are also socially constructed. ${ }^{1}$ Networks split oceans, creating different sectors and alignments within a waterbody. While Steinberg searches for a Mediterranean in the Pacific, the North Pacific and the North-central and West Pacific respectively are focal for Jones and Ravalli by way of Russian and Japanese networks, Igler meanwhile rooting for an East Pacific, arguing that the "much of the eastern Pacific was now the American West." ${ }^{2}$ We see therefore that while large-scale generalisations are essential to a world historical approach such generalisations are constantly modified in light of new research, leading towards the centrality of the region and its particular networks. The issue here is whether world history is becoming-not transhistorical-but the new regional history.

$$
* * *
$$

Space therefore becomes an important component in writing a world history, a major criticism against a world historical approach being the "death of distance" and the affirmation of homogeneities. ${ }^{3}$ The question of the incorporation of diverse regions remains, as does the crucial problem of time in world history. As Beaujard reminds us, East Africa remains part of global history only until $1500 .{ }^{4}$ But for Boucheron the first complete globalisation occurred only in the fifteenth century. ${ }^{5}$ How do we

* Institut de Chandernagor and University of Hyderabad, India.

${ }^{1}$ Daniel Nordman, "La Mediterranee dans la pensee geographique francaise (vers 1800-vers 1950)," in From the Mediterranean to the China Sea: Miscellaneous Notes, ed. Claude Guillot, Denys Lombard, and Roderich Ptak (Wiesbaden: Harrassowitz Verlag, 1998), 1-20.

${ }^{2}$ Philip E. Steinberg, “The Pacific: A Mediterranean in the Making?” Geographical Review 89, no. 2 (April 1999): 265-77; Ryan Tucker Jones, “The Land Yields to the Sea: The Possibilities of Ocean History," in Writing a Water History (working title), ed. Rila Mukherjee (forthcoming); Richard Ravalli, "The Sea Otter Islands: Geopolitics and Environment in the East Asian Fur Trade,” Asia Pacific Perspectives 9, no. 2 (June 2010): 27-35; David Igler, "Diseased Goods: Global Exchanges in the Eastern Pacific Basin, 1770-1850," The American Historical Review 109, no. 3 (June 2004): 693-719.

${ }^{3}$ Frances Cairncross, The Death of Distance: How the Communications Revolution Will Change Our Lives (Boston, Mass.: Harvard Business School Press, 1997); Robert McCormick Adams, "Contexts of Civilizational Collapse," in The Collapse of Ancient States and Civilizations, ed. N. Yoffee and G. L. Cowgill (Tucson: University of Arizona Press, 1988), 20-43.

${ }^{4}$ Philippe Beaujard, "Systemes-Mondes Anciens, Processus de Domination, de Coevolution et de Resistance. L'Exemple de la Cote Est-Africaine Avant le XVIIe siecle,” Actuel Marx 53 (2013): 40-62.

${ }^{5}$ Patrick Boucheron, Histoire du Monde au 15e siecle, 2 vols. (Paris: Pluriel, 2012), vol. 1: Lands and Writings; vol. 2: Times and Futures. 
deal with such seemingly divergent tendencies and disparate approaches?

Holstein proposes the strategy of comparing, connecting, conceptualising and contextualising in writing world history. ${ }^{6}$ Manning suggests six axes of interrogation for world historians. For him spatial analysis of historical connections is complex, addressing large regions and small, regional comparisons and interactions, and patterns of the global space. Along the axis of space world historians have joined the debate of national vs. global frameworks for history, and are beginning to address more explicitly the linkages of global and local. Space for Manning, however, is only one dimension of the issues to be considered by world historians. Alongside the complex dimension of space one must consider the dimensions of time and topical breadth, each with its complexities. Along the axis of time, world historians are beginning to develop long-term interpretations of historic change, and are working up to a critique of the overwhelming focus of existing historiography on the past two centuries. Along the axis of topical breadth, world historians face the question of which topics to emphasize-from cultural to geological-and which disciplines to use and combine in exploring them. The three dimensions or axes of space, time, and topical breadth make explicit the immense potential range of world historical studies. Summarizing to this point, there is a growing understanding that the "global" in global history means not just the range of regions, but the range of time frames and the range of topical emphases and interactions. The other three axes are the scale of analysis, the philosophy of the analyst/historian and the necessity of verification. ${ }^{7}$

Dirlik notes however "a tendency in most world history writing to take as the point of departure for historical analysis modern conceptions of historical spaces, most prominently nations, civilizations, and on occasion even cultures. There are good historiographical reasons for doing so. After all, one of the fundamental tasks of history is to find in the past clues to the

\footnotetext{
${ }^{6}$ Diego Holstein, Thinking History Globally (New York: Palgrave Macmillan, 2014).

${ }^{7}$ Patrick Manning, "Concepts and Institutions for World History: The Next Ten Years,” in World History: Global and Local Interactions, ed. Manning (Princeton: Markus Wiener Publishers, 2006).
} 
economic, social, political, and cultural formations of the present. Contrary to premature declarations of their impending demise, nations and civilizations still represent the fullest articulations of these formations. 'Artifices' of history do not lose their historical significance-the power to shape history-simply because they are demonstrably artifices of history. Civilizations, nations, cultures, and continents may all be constructs of modernity; nevertheless, they have been essential in giving modernity its shape and meaning (but) spaces implied by nations and civilizations are products rather than subjects of complex historical interactions. Greater emphasis on these interactions and the proliferation of spaces it demands yields a far more complicated, albeit anarchic, conception of world history."

The difference/s between "world," "global," "regional," and "local" are considered in the essays, a consensus emerging about the problems inherent in the historiography of the use of the terms themselves. Because, as Dirlik notes elsewhere, the problems that world history presents are not just ideological; they are also narrative problems. To this would have to be added the ways in which the world has been conceived of over time; in other words, the spatio-temporal dimensions of the idea of "the world" and how these have been delineated in historiography. World history persists ultimately because of a conviction that differences that mark the world and its past may be contained within a single grand narrative, much like the Foucauldian condemnation of a histoire totale. World history has to confront the problem that the very crowding of diverse peoples and places into history may mean the end of history as we know it because, if those people and places are recognised genuinely in their differences, they cannot be contained within a single narrative. The problem of narrative has become apparent in a range of historiographies, but the example that is most pertinent to the issue of globalization may be that of different "cultures" being incorporated into a single narrative of world history, which may end up

${ }^{8}$ Arif Dirlik, "Performing the World: Reality and Representation in the Making of World Histor(ies)" (Keynote address presented at the Teaching World History conference at the GHI, March 3, 2005), Bulletin of the German Historical Institute 37 (Fall 2005): 9-25, $10-11$. 
exploding the whole notion of world history and, with it, history itself. $^{9}$

Also, while categories such as nation, civilisation, race, continent and culture-determined by scale, typicality, aggregation and capacity for abstraction-remain points of reference in writing a world history, such universal categories can and do change over time, as Michel de Certeau's idea of history teaches us. ${ }^{10}$ Bentley too cautioned us in dealing with large scale cultural processes: "Although difficult to account for, processes of large-scale cultural change call for historians' careful attention. Alongside cross-cultural trade and biological exchanges, they help to explain the social and cultural environments in which most of the world's peoples have led their lives." The essays by Banerjee and Mukhopadhyay explore universal and world-historical categories through the trope of civilisational discourse and the notion of a shared urbanity.

\section{$* * *$}

Salles addresses the description of world history in antiquity, noting that while the "world" doesn't appear in the earliest global book, the Bible, the idea of humanity does appear as a form of shared labour. Stressing exchanges in the early period, Salles sees a shift towards world history in Antiquity as the norms for writing history changed radically after the birth of Christ. Salles traces the shift from the world-view of the Greeks to the more limited world-view of the Romans, the narrower notion of history predominating in medieval Europe being inaugurated during the Roman era.

Braudel made waterscapes central to political imaginaries for the early modern period. ${ }^{12}$ His oceanic approach generated a corpus of maritime histories as "world history," in which the In-

${ }^{9}$ Arif Dirlik, "Globalization as the End and the Beginning of History: The Contradictory Implications of a New Paradigm,” Rethinking Marxism 12, no. 4 (2000): 4-22.

${ }^{10}$ Michel de Certeau, The Writing of History, trans. Tom Conley (New York: Columbia University Press, 1988).

${ }^{11}$ Jerry H. Bentley, “Hemispheric Integration, 500-1500 C.E.,” Journal of World History 9, no. 2 (Fall 1998): 237-54.

${ }^{12}$ Maria Fusaro, "After Braudel: A Reassessment of Mediterranean History between the Northern Invasion and the Caravane Maritime," in Trade and Cultural Exchange in the Early Modern Mediterranean: Braudel's Maritime Legacy, ed. Maria Fusaro, Colin Heywood, and Mohamed-Salah Omri (London: I. B. Tauris, 2010), 1-22. 
dian Ocean has played no small part. Chakravarti however pleads for a de-centering of Indian Ocean history from the twin shackles of the meta-histories of the nation-state and of restrictive regional histories by citing an absence of the nation-state in the Indian Ocean in the pre-1500 period. Reiterating the need for a different lens to study Indian Ocean history in the pre-1500 period, Chakravarti suggests that although the Indian Ocean in the post 1500 period is studied by using approaches such as connected histories, a better idea would be to use the notion of braided histories to investigate the period before 1500 .

Polónia continues the theme of oceanic histories as world history, concentrating on Atlantic transfers. She advocates environmental history as world history from the time European colonialism constituted the New World. Taking as point of departure the depletion of economic and environmental resources, Polonia argues that the European conquest of the New World was the conquest of wilderness just as the rise of environmentalism signified its end. Polonia also notes that while colonialism was primarily a European enterprise other dimensions of this project reveal the nature of histories Europeans produced. The shift to environmental history, according to Polonia, promises to reveal newer facets in world history.

Banerjee questions the role of world-historical categories such as humanism and universalism in constructing a world history. The nineteenth century Bengali reformer Raja Ram Mohan Roy's engagement with Persian, and not English, was seen to be a wider window to the world of his time. Banerjee interrogates Roy's personality and situational context to understand how far the main global currents shaped his idea of eclecticism, emphasizing in the process Pomeranz's notion of aggregation, since Roy's thoughts synthesized many different currents. Banerjee investigates whether Roy was skeptical of both global and local history, concluding that Roy's exercise can be seen as an exemplar of engaging with world history and thus offering possibilities to be re-read in newer ways. But, Banerjee asks: is the crosscultural always global?

Mukhopadhyay tests another dominant discourse: the ideal of an Islamic city as a world-historical category and its preva- 
lence in different parts of the world as a historical reality. Mukhopadhyay questions this ideal as template for world history. Taking as point of departure the works of established Islamist scholars, Mukhopadhyay finds that the ideal Islamic city with a precise and seemingly pre-ordained layout of mosque, market, madrassa and fort remains largely confined to the North African prototype and is therefore inapplicable as a world historical model. Mukhopadhyay concludes that the idea of writing world history through the notion of unity and of shared urbanity by taking up the case of the Islamic city as model is not viable.

Can oceanic history be studied as world history? Taking specific instances of histories of the Atlantic, the Pacific and the Mediterranean, Pearson ends this collection by interrogating a history of the sea as world history, where the global approach so far useful for geographers rather than the world systems approach would also shed light on the new project towards writing a world history. Significantly, Pearson concludes by throwing up the problems of writing a global history of oceans, taking the Pacific Ocean as example, and rejects the category of the ocean as universal template for world history. In Pearson's words, "the variations are so profound that we may decide the Pacific, or maybe any other ocean, is simply not a category or template which we can use to write world history." ${ }^{3}$

$* * *$

World history obviously cannot be the history of the world as Bentley had pointed out but the problem needs to be pegged at the points of reference. ${ }^{14}$ Which world, at which point of time and what levels of world-making are we talking about? Many text books point to a narrow view of the world and a satisfactory definition of the "world" in "world history" is yet to be attempted.

But there still remains certain ambivalence about the term "world" history. Should we then use the term "world histories" rather than "world history"? Traditionally, the "world" has been

${ }^{13}$ For a contrary view, see Ryan Tucker Jones, "Running into Whales: The History of the North Pacific from below the Waves," The American Historical Review 118, no. 2 (April 2013): 349-77.

14 Jerry H. Bentley, "Cross-Cultural Interaction and Periodization in World History," The American Historical Review 101, no. 3 (June 1996): 749-70. 
the inhabited world; but what of the oceanic spaces, or the deserts, which, if nothing else, have to be traversed, in order to get from one inhabited area to another? Are these worlds in themselves, or are they merely zomian spaces to be crossed to get to inhabited, known, controlled spaces?

And finally, this collection played with the categories of "global" history and "world" history. Since the two terms are often used interchangeably it is important we interrogate their lineages as well as understand their construction in the twentieth century. Tracing the shifts from the universal histories and encyclopedias so prevalent in the seventeenth-eighteenth centuries to the Annales project of total history in the twentieth century, we see that global history has two meanings: in the French sense it is seen as the successor to total history (histoire totale), while in Anglo-Saxon usage it is synonymous with world history. Foucault advocated a histoire generale against total/global history because the latter category generated an unifying meta-narrative that obscured rather than illuminating divergences, bringing history into a pre-determined future. ${ }^{15}$ This critique of global history was ignored in Anglo-Saxon history-writing and potential alternative paths remain unexplored.

Except in Dirlik's writings. Like Foucault, Dirlik refers to a "world-history-as-totality," in which the world/globe becomes the ultimate frame of reference in the investigation and explanation of the forces shaping past and present. This option necessitates the practice of world history but renders it problematic. Rather than organizing the world in terms of the spaces of nations and civilizations, this perspective calls for a view of nations and civilizations in their historicity, not only as possessing beginnings and endings of their own, but as being by their very nature more process than finished product. The issue here is not to find a transcendent perspective that defies concrete grounding and supersedes spatial partiality. It is rather to confront the contingencies and ground-level processes of human activity with the structures that are at once the products and the conditions of that activity. World-history-as-totality refers not just to abstract

${ }^{15}$ Michel Foucault, The Archaeology of Knowledge, trans. A. M. Sheridan Smith (London and New York: Routledge, 2002). 
structural totalities, but even more importantly to a perspective that demands deconstruction-most importantly, historicization-of the spaces that conventionally have been rendered into containers of history; not just nations and civilizations. Worldhistory-as-totality is radical in its theoretical and methodological implications because it calls for the proliferation of space in historical analysis beyond those of economic, cultural, and political power and for recognition of the historical interaction between many spaces that produce, but are also conditioned by, structural totalities of various kinds: from nations and empires to the world-systems of capital. Ethnic and diasporic spaces are examples of such spaces that often are described, somewhat misleadingly as "transnational" spaces. Such spaces preceded in their existence the emergence of nations; they may not be of equal significance to all parts of the nation, in which case they may help undermine its unity and homogeneity, and they are quite likely to outlast the nation as we have known it. "Translocal" is a better term, being both more grounded and more flexible to describe the motions that create these spaces. The move from the transnational to the translocal carries us from one conceptual realm, that of nations and civilizations or spaces, to another: that of places. $^{16}$

The historicity, boundary instabilities, and internal differences-indeed fragmentations-of nations, civilizations, and continents underline the historiographically problematic nature of world histories organized around such units. They are products of efforts to bring political or conceptual order to the world, an order achieved only at the cost of suppressing alternative spatialities and temporalities as well as covering over processes that went into their making. ${ }^{17}$ This issue of $A R W H$ therefore is as much concerned with problematising world history, as it is with the ways of writing world history.

${ }^{17}$ Ibid., 18-19; Matthias Middell and Katja Naumann, "Global History and the Spatial Turn: From the Impact of Area Studies to the Study of Critical Junctures of Globalization,” 